Newfoundland and Labrador Studies

\title{
Introduction to the Basque Papers
}

\section{Brad Loewen}

Volume 33, numéro 1, 2018

URI : https://id.erudit.org/iderudit/1055863ar

DOI : https://doi.org/10.7202/1055863ar

Aller au sommaire du numéro

Éditeur(s)

Faculty of Arts, Memorial University

ISSN

1719-1726 (imprimé)

1715-1430 (numérique)

Découvrir la revue

Citer ce document

Loewen, B. (2018). Introduction to the Basque Papers. Newfoundland and

Labrador Studies, 33(1). https://doi.org/10.7202/1055863ar d'utilisation que vous pouvez consulter en ligne.

https://apropos.erudit.org/fr/usagers/politique-dutilisation/ 


\section{Introduction to the Basque Papers}

Brad Loewen

The inspiration for this collection of papers lies in a 2016 conversation with Miren Egaña Goya, linguist and historian in Donostia-San Sebastián, in which she expressed the desire to tell Newfoundland and Labrador residents of the rich Basque heritage that is preserved in their province. Basques see Canada as a vital chapter in their history, a land in which they worked and prospered for centuries, forged many strong and tender ties with First Nations, and were obliged to leave against their will as a result of colonial wars. They are mindful that Canadian citizens and governments are today the guardians of this unique and irreplaceable heritage. Many Basques feel a need to engage in a meaningful dialogue with residents of Newfoundland and Labrador about their shared sense of historical place and belonging.

Basques were not only whalers in the far-off sixteenth century on a short stretch of the southern Labrador coast. When their whaling stations closed down, they regrouped and laid claim to more than a hundred ports throughout western and southern Newfoundland, Cape Breton Island, Chaleur Bay, and the St. Lawrence Estuary. Their activities attained their greatest geographic extent, economic diversity, and social complexity over the course of the seventeenth century. Some continued to hunt whales, but many more fished, sealed, and traded with Indigenous peoples and sedentary fishing communities. Their resilience and cultural continuity in the face of colonial disruptions are a remarkable aspect of their presence in this large territory. From the sixteenth century onward, Basques left a trail of historical, 
archaeological, linguistic, funerary, toponymic, and patronymic footprints that join directly with our own time. This record is not the plaything of a few scholars, but the taproot of a living cultural identity that imparts its dignity, gravitas, and immediacy to what researchers do with it.

The papers in this volume have a special focus on seventeenthcentury Newfoundland and Labrador. It was during this century that Basques consolidated their place in Canada. Some aspects of the sixteenth-century transatlantic fisheries may be compared to a gold rush, in that profits were high and access to resources was almost unrestricted. Beginning about 1580, declining profits and conflicts over resources - among Europeans and with Indigenous peoples - drastically changed the playing field. In this new and challenging context, Basque determination to remain in Canada required a series of adaptations, which produced an evolving record of cultural agency. The seventeenth century tells the story of Basque agency and adaptation within a shared, rapidly changing landscape.

In contrast to the isolation of sixteenth-century whalers in Labrador, Basque presence took on a more complex, relational aspect in the seventeenth century. Today, many Basques see their own country as a colonized land, and their identity in terms of resistance to French and Spanish colonization. This view has some historical extensions to the Basques' experience in Canada. Basques tended to be excluded from the French colonial project, a situation that led to examples of distinctive relations with Indigenous peoples. Underlying these relations was a need to compete with growing numbers of sedentary fishers, whose year-round presence brought advantages that the migratory Basques did not enjoy. Indigenous "partnerships" allowed Basques to gain some of the same advantages of a local labour force, access to winter resources such as animal skins, and locally produced food, fuel, boats, and building materials. An indirect indicator of these partnerships is the historical incidence of Basque names among Inuit, Mi'kmaw, and Métis families in southern Labrador, Cape Breton Island, and parts of Gaspésie. While these partnerships did not change the fact that 
only Basques had access to European capital and markets, they differed from sedentary colonialism in that they did not result in Native expulsion from European settlement areas, or in a deepening spiral of competition, fear, and conflict. French missionaries and administrators often betrayed a mistrust of the relation between Basques and Indigenous people that was itself a form of adaptation and agency in an adverse colonial context.

The tenuous relationship between Basque fishermen and French colonialism arose, in large part, from the fact that most Basque fishermen were not French citizens. Basques residing in France and Spain tended to collaborate within an integrated cross-border economy, favoured by their common culture and language. Not unlike the Catalans, Basques were particularly impacted by Franco-Spanish wars. Meetings between the Saint-Jean-de-Luz and San Sebastián admiralties to uphold cross-border trade and the New France fishery were much more regular than incidents when warships trained their guns at fellow Basques. As the balance of power shifted in France's favour over the course of the seventeenth century, Basque outfitters and captains from Spain were forced into commercial concessions that increased their reliance on supplies and capital from France. As a result, Basque material culture in Canada gradually shifted from an Iberian to a French spectrum. Over the same time, New France authorities worked to reduce the areas of "Spanish" fisheries, especially in the northern Gulf of St. Lawrence. Basque reaction to French colonial pressure left a litany of historical claims, legal counter-actions, and, occasionally, muscular resistance. The bibliographic survey at the end of this introduction provides the major references to the complex Basque narrative that played out in the ever-narrowing space between Indigenous and colonial experiences.

Scholars in Newfoundland and Labrador are increasingly at ease with French and Spanish literature. In conversation with Miren Egaña Goya, however, we realized that the goal of opening a dialogue with Basques would best be served by publishing in English, in a forum based in the province. Mindful of this goal, I have spared no effort 
in bringing research to readers in English. I see this as an investment that will certainly be returned a hundredfold by new generations of scholars. This issue of Nerwfoundland and Labrador Studies is above all an invitation to pursue research into the many facets of Basque heritage introduced here.

\section{The Papers}

While the papers in this issue may be read separately, they also build a common narrative that is reflected in their order of appearance. The first three papers show the Basques in relation to Indigenous peoples of Newfoundland, Labrador, and along the north shore of the Gulf of St. Lawrence.

Vincent Delmas reviews the archaeological data showing an Indigenous presence on Basque sites from the Strait of Belle Isle to the Saguenay River. The extensive amount of data and the number of sites on which they appear have not previously been noticed. Archaeologists working on these sites, often in isolation, have hesitated to suggest a direct relationship between Basques and local Indigenous people on individual sites. However, Delmas urges archaeologists to reconsider the data as a whole, since the recurring pattern of Indigenous materials on Basque sites indicates a wealth of material relationships between Basque crews and Innu, Iroquoian, and Inuit peoples.

Javi Castro presents historical evidence of Basque sealing in Labrador, and follows the chaine opératoire of sealskins through the tanning, shoemaking, and export trades of two secondary ports in Gipuzkoa. Sealskins were used to make watertight sailors' boots for the Newfoundland fishery, and some boots were worn in Labrador by overwintering Basque sealers. Castro relates the sealskin economy to the arrival in the Basque Country in about 1620 of an Inuit family - as well as their kayak that decorated a local church for about 350 years. Sealing thus appears as a focus for Basque-Inuit contact in the seventeenth century. 
Greg Mitchell and Ihintza Marguirault examine the written record of Inuit personal names in Labrador, from 1694 to 1834, for indicators of Iberian names and surnames. They suggest that these names represent the oldest layer of historical identity construction among Indigenous Labrador people, prior to the Moravian missions of the 1770s and likely arising during the time of Basque whaling, sealing, and fishing in the Strait of Belle Isle. The possible Spanish or Basque origin of Inuit names provides an original window on cultural relations that likely arose in the seventeenth century.

Relations between Basques and French are examined in the following four papers. Nicolas Landry surveys historical data on relations between Basque fishermen and French colonial authorities at Placentia. The French colonial archives he has studied show Basque ships sailing from Saint-Jean-de-Luz and Bayonne in the Basque province of Lapurdi (France). While these archives reflect the French official point of view, they also show the cohesiveness of the entire Basque fishing fleet and its ability to decisively aid or confront colonial authorities, depending on the circumstances.

Gaëlle Dieulefet presents the material culture from a shipwreck site at Isle aux Morts in southwest Newfoundland, dated between 1638 and about 1690. Based on the range of ceramics and technological similarities to the San Juan that sank at Red Bay, Labrador, in 1565, she argues that this ship had a Basque origin - perhaps from Spain - and was outfitted by Saint-Jean-de-Luz merchants. This site is the clearest archaeological example of seventeenth-century Basque fishing activity, and shows the increasing complexity of the Basque archaeological record after the Red Bay whaling enterprise.

Miren Egaña Goya analyzes the Basque gravestones preserved at Placentia. She shows that the Placentia burying ground was already used in the sixteenth century for Basque fishermen who died in Newfoundland. Linguistic analysis of the inscriptions sheds light on the identity and origin of the interred sailors, while stylistic analysis attaches these monuments to an ancient Basque funerary tradition. One 
tombstone, inscribed in French, identifies a Basque corsair whose illustrious career ended tragically in Newfoundland.

Finally, Catherine Losier and co-authors Brad Loewen and Miren Egaña Goya consider the different European cultural groups that occupied much of Newfoundland for two centuries before 1713 . They see a need for greater cultural precision in conceptualizing these groups that are often rather broadly described as "French and Basque," and provide keys for distinguishing four major archaeological complexes. In addition to suggesting a historical framework for further study, they use a key source for Newfoundland, the 1677 piloting book of Piarres Detcheverry, to reconstruct the Basque cultural landscape in southern Newfoundland and Saint-Pierre-et-Miquelon.

\section{The Future of Research on the Basques}

When I was looking for a way to bring these papers to readers in Newfoundland and Labrador, Peter Pope, a fine colleague who recently passed away, suggested Newfoundland and Labrador Studies. Dr. Pope's interest in the seventeenth-century fisheries went beyond the English pale of Avalon and took him to Placentia, western Newfoundland, and especially the Petit Nord. I was astonished by the originality of his findings that show a Breton archaeological presence fully on a level with the Basque sites in Labrador. Dr. Pope led me to see Newfoundland and Labrador in new ways, and like him, I am convinced that the province's seventeenth century holds a major new chapter waiting to be written.

Concerning the Basques in particular, I see a need to go beyond the Labrador whale hunt and delve into the broader, more complex question of seventeenth-century adaptations. As a border people, Basques were affected by the shift in power from Spain to France, both in Europe and in Canada. As mostly Spanish residents, they were excluded from the colonial sedentary fisheries and sought to gain comparable advantages by building in situ "partnerships" with Indigenous peoples. In their strategic relations with Inuit, Iroquoians, and some 
Mi'kmaw groups, Basques sometimes transmitted a sense of rivalry with New France that subsequent English colonizers would reactivate to their own benefit. It would be wrong to think that the Basque chapter was somehow isolated from wider European, Indigenous, and colonial questions.

\section{Bibliographic Survey of the Basques in the Seventeenth Century}

Despite this entangled past, the Basques themselves are at the heart of their own history and archaeology. Understanding their seventeenth-century adaptations relies on a Verstehen intellectual stance, and therein lies a significant challenge for non-Basque researchers. That said, it is not as if we are starting from an empty slate. For those wishing to discover the seventeenth-century Basques in Canada as a research subject, I have prepared a bibliographical survey aimed at students preparing a term paper, a literature review, or an oral exam field.

An approach to the seventeenth-century Basque fisheries should begin with the pioneering historical work of Enrique de Gandía in 1942, René Bélanger in 1971, and Selma (Huxley) Barkham in 1987. Despite their exploratory nature, these works remain current for the great amount of data they contain. Additional data on the seventeenth century can be gleaned from the books of Mariano Ciriquiain Gaiztarro (2010) and José Antonio Azpiazu (2008, 2016), and from the doctoral dissertation of Laurier Turgeon (1982). The careers of two Basque merchants, although separated by a full century, are known thanks to Michael Barkham (1994) and Nicolas Landry (2001). On the question of relations between Basque fishermen and growing French power, key references are the colonial perspectives of René Bélanger (1971) and Miren Egaña Goya (2010), a study of cross-border Basque diplomacy by Caroline Lugat (2006), and the analysis of the cross-border Basque economy by Álvaro Aragón Ruano and Xabier Alberdi Lonbide (2007).

Maps and pilot books provide an indispensable geographic overview of Basque presence in eastern Canada. In addition to Selma (Huxley) Barkham (1989) and Christian Weyers (2009), Miren Egaña 
Goya especially has mined the rich vein of Basque toponymy from a linguistic angle and has analyzed the pilot books of Martin de Hoyarsabal (1579) and Piarres Detcheverry (1677) (Egaña Goya, 1992, 1994, 1995, 2002). Loewen and Egaña Goya (2014) have translated and examined the Chaleur Bay portion of the Basque-language pilot book by Detcheverry. Providing a postlude to the period under review here, and a starting point for the eighteenth century, are studies by JeanPierre Chrestien and Daniel Dufournier (1995), Pierre Nadon (2004), and Mario Mimeault (2009) covering the French colonial regions of Acadia and Gaspésie, around the southern Gulf of St. Lawrence.

An archaeological focus on the seventeenth century remains to be constructed. In their overview, Brad Loewen and Vincent Delmas (2012) remarked that 1630-1713 was the least known period of Basque presence around the Gulf of St. Lawrence. A breakthrough was gained by the fieldwork of William Fitzhugh on Petit-Mécatina Island, bringing to light new ceramic assemblages and evidence of the site's cohabitation by Basques and Inuit (Fitzhugh et al., 2011; Fitzhugh, 2015; Herzog, 2011; Herzog and Moreau, 2006). The starting point for studying Basque-related ceramics is Gerard Gusset's work on Red Bay (Gusset, 2007). Important updates have been provided by the Ph.D. dissertation of Sergio Escribano-Ruiz (2014) on post-medieval ceramics in the Basque Country, and the M.Sc. thesis by Saraí Barreiro Argüelles (2014) on ceramics found on Basque sites in Canada. These works being in Spanish, Escribano-Ruiz and Barreiro Argüelles (2016) have usefully provided an English synthesis. In addition, the doctoral dissertation by Vincent Delmas (2018) discusses all the Basque sites in the northern Gulf of St. Lawrence, from the Saguenay to the Atlantic.

An eclectic array of approaches underlies the study of relations between Basques and Indigenous peoples in the seventeenth century. Interest for this subject arose from linguists who examined BasqueIndigenous trade pidgins and Basque-Icelandic maritime vocabularies (Bakker, 1989, 1996; Irujo and Miglio, 2015). Studies with a more regional focus, highlighting Basque relations with specific Indigenous 
groups, rely on diverse sources. Brad Loewen has published an essay on the entanglement of Basques and Iroquoians in the sixteenth and early seventeenth centuries, as well as a reassessment of relations between Basques and Inuit in the seventeenth century (Loewen, 2016a, 2017). Material culture has provided many insights into these relations. Examples include the lauburu emblem (Bakker, 1991), the chaloupe biscaïenne (Loewen, 2016c; Crompton and Rankin, 2017), copper kettles (Turgeon, 1997; Michelaki et al., 2015), iron nails (Rankin and Crompton, 2016), roof tiles (Jordan and Kaplan, 1980), moose hides (Turgeon, 1998), and glass beads (Delmas, 2016; Loewen, 2016b).

Numbering more than 40 , these references include few recent monographs, showing the need for an updated synthesis of research that is dispersed in many journals and volumes. It is my hope that the present volume will stimulate new interest for a vast area of research.

\section{References}

Aragón Ruano, Álvaro, and Xabier Alberdi Lonbide. 2007. "Relaciones comerciales entre puertos franceses y guipuzcoanos en las décadas finales del siglo XVI y la primera mitad del siglo XVII: síntoma de vitalidad económica." Pedralbes (Barcelona) 27:219-62.

Azpiazu, José Antonio. 2008. La empresa vasca de Terranova: Entre el mito y la realidad. Donostia-San Sebastián: Ttarttalo. - 2016. Hielos y oceanos: Vascos pour el mundo. Donostia-San Sebastián: Ttarttalo.

Bakker, Peter. 1989. “'The language of the coast tribes is half Basque': A Basque-American Indian pidgin in use between Europeans and Native Americans in North America, ca. 1540-ca. 1640." Anthropological Linguistics 31: 117-47.

—.1991. "The mysterious link between Basque and Micmac art." European Review of Native American Studies 5, 1: 21-24. - 1996. "Language contact and pidginization in Davis Strait, Hudson Strait, and the Gulf of Saint Lawrence (northeast Canada)." In Erwin H. Jahr and Idris Broch, eds., Language Contact in the Arctic: Northern Pidgins and Contact Languages, pp. 261-310. Trends 
in Lingusitics Studies and Monographs 88. Berlin: Mouton de Gruyter.

Barkham, Michael M. 1994. "French Basque 'New Found Land' entrepreneurs and the import of codfish and whale oil to northern Spain, c. 1580 to c. 1620: The case of Adam de Chibau, burgess of Saint-Jeande-Luz and 'Sieur de St. Julien'." Nerwfoundland Studies 10, 1: 1-43.

Barkham, Selma (Huxley). 1987. "Los Vascos y las pescerías transatlánticas, 1517-1713.” In Enrique Ayerbe and Selma (Huxley) Barkham, eds., Itsasoa 3. Los Vascos en el marco Atlántico Norte, Siglos XVI y XVII, pp. 26-189. San Sebastián: Editorial ETOR.

-1989. The Basque Coast of Nerwfoundland. Plum Point, NL: Great Northern Peninsula Development Corporation.

Barreiro Argüelles, Saraí. 2014. "Ciudadanos del Atlántico. Las redes de aprovisionamiento transatlánticas de las pescas vascas en Canadá a través de su cerámica, siglos XVI-XVIII.” Master's thesis, Département d'anthropologie, Université de Montréal.

Bélanger, René. 1971. Les Basques dans l'estuaire du Saint-Laurent. Montréal: Les Presses de l'Université du Québec.

Chrestien, Jean-Pierre, and Daniel Dufournier. 1995. "Les grès béarnais au Canada." In Jean Bourgoin and Jacqueline Carpine-Lancre, eds., L'aventure maritime, du golfe de Gascogne à Terre-Neuve, pp. 251-70. Paris: Éditions du CTHS.

Ciriquiain Gaiztarro, Mariano. 2010 [1961]. Los vascos en la pesca de la ballena. Donostia-San Sebastián: Txertoa Reprints.

Crompton, Amanda, and Lisa Rankin. 2017. "Chaloupes and kayaks: European mariners and the seascapes of inter-cultural contact." In Hein Bjerck, ed., Marine Ventures: Archaeological Perspectives on Human-Sea Relations, pp. 311-23. Sheffield: Equinox Publishing.

Delmas, Vincent. 2016. "Beads and trade routes: Tracing sixteenth-century beads around the Gulf and into the Saint Lawrence Valley." In Brad Loewen and Claude Chapdelaine, eds., Contact in the 16th Century: Networks among Fishers, Farmers and Foragers in the Northeast, pp. 77-115. Ottawa: University of Ottawa Press. - 2018. "Les pêcheurs basques au Canada, 1530-1760. De la culture matérielle à l'identité culturelle." Ph.D. dissertation, Département d'anthropologie, Université de Montréal. 
Egaña Goya, Miren. 1992."Basque toponymy in Canada." Onomastica canadiana 74, 2: 53-74.

. 1994. "XVI eta XVII mendeetako Canadako Ternua eta Labrador-eko euskal leku-izenen zenbait berri." Anuario de Eusko-Folklore 32: 31-41.

.1995. "Les toponymes basques au Québec." Le Naturaliste canadien 119, 1: 54-57.

—. 2002. "Le plan géométral de l'île de Terreneuve'. Lécole basque de cartographie.” Zainak, Cuadernos de Antropologia-Ethnografía 21: 253-67.

-2010. "Presencia de los pescadores vascos en Canadá, s. XVII. Testimonio de la obras de Samuel de Champlain (1603-1633)." Zainak, Cuadernos de Antropologia-Ethnografia 33: 275-393.

Escribano-Ruiz, Sergio. 2014. "Genealogía del registro cerámico alavés de época preindustrial (Siglos XIV al XVII).” Ph.D. dissertation, Universidad del País Vasco - Euskal Herriko Unibertsitatea, Vitoria-Gasteiz.

and Saraí Barreiro Argüelles. 2016. "Travelling ceramics: Basque networks and identities in the Gulf of Saint Lawrence." In Brad Loewen and Claude Chapdelaine, eds., Contact in the 16th century: Networks among Fishers, Foragers and Farmers, pp. 31-55. Ottawa: University of Ottawa Press.

Fitzhugh, William W. 2015. “The Inuit archaeology of the Québec Lower North Shore."Études/Inuit/Studies 39, 1: 37-62.

— Anja Herzog, Sophia Perdikaris, and Brenna McLeod. 2011. "Ship to shore: Inuit, early Europeans, and maritime landscapes in the northern Gulf of St. Lawrence." In Ben Ford, ed., The Archaeology of Maritime Landscapes, vol. 2, pp. 99-128. New York: Springer.

Gandía, Enrique de. 1942. Primitivos navegantes vascos. Buenos Aires: EKIN. Gusset, Gérard. 2007. "La poterie commune et le grès des sites subaquatique et terrestre à Red Bay." In R. Grenier, M.-A. Bernier and S. Willis, eds., L'archéologie subaquatique de Red Bay. La construction navale et la pêche de la baleine basque au XVIe siècle, vol. 2, ch. 9. Ottawa: Parks Canada.

Herzog, Anja. 2011. "Lîle du Petit Mécatina sur la Basse-Côte-Nord du Québec. Résultats préliminaires des analyses céramiques d'un site voué 
aux activités de pêche saisonnière dans le golfe du Saint-Laurent entre le XVI et le XVIII ${ }^{\mathrm{e}}$ siècle." In Steven R. Pendery and Fabienne Ravoire, eds., Migrations, transferts et échanges de part et d'autre de l'Atlantique. Histoire et archéologie des XVI et XVII siècles, pp. 121-41. Paris: Éditions du CTHS.

- and Jean-François Moreau. 2006. "European glass trade beads, neutron activation analysis, and the historical implications of dating seasonal Basque whaling stations in the New World.” In J. Pérez-Arantegui, ed., 34th International Symposium on Archaeometry, pp. 495-502. Zaragoza, Spain: Institución Fernando el Católico, Diputación de Zaragoza. http://ifc.dpz.es/recursos/publicaciones/26/10/_ebook.pdf (accessed July 2016).

Irujo, Xabier, and Viola J. Miglio, eds. 2015. Basque Whaling in Iceland in the XVII Century: Legal Organization, Cultural Exchange E Conflicts. Santa Barbara, Calif., and Hólmavík, Iceland: Barandiaran Basque Studies Series and Strandagaldur.

Jordan, Richard, and Susan A. Kaplan. 1980. "An archaeological view of the Inuit/European contact period in central Labrador." Études/Inuit/ Studies 4, 1/2: 35-45.

Landry, Nicolas. 2001. "La société de Lasson-Daccarrette à Plaisance, 1700-1715.” Nerwfoundland Studies 17, 2: 220-56.

Loewen, Brad. 2016a. "Intertwined enigmas: Basques and Saint Lawrence Iroquoians in the 16th century." In Brad Loewen and Claude Chapdelaine, eds., Contact in the 16th Century: Networks among Fishers, Foragers and Farmers, pp. 57-75. Ottawa: University of Ottawa Press. _. 2016b. "Sixteenth-century beads: New data, new directions." In Brad Loewen and Claude Chapdelaine, eds., Contact in the 16th century: Networks among Fishers, Foragers and Farmers, pp. 269-86. Ottawa: University of Ottawa Press. - 2016c. "Cultural transmissions of the 'Biscayne Shallop' in the Gulf of St. Lawrence, 1560-1750.” In Amanda M. Evans, ed., The Archaeology of Vernacular Watercraft, pp. 165-87. New York: Springer. - 2017. "The world of Capitena Ioannis: Basques and Inuit in the 17th century." Canadian Journal of Archaeology 41: 165-203.

— and Vincent Delmas. 2012. "The Basques in the Gulf of St. Lawrence and adjacent shores." Canadian Journal of Archaeology 36: 351-404. 
and Miren Egaña Goya. 2014. "Le routier de Piarres Detcheverry, 1677. Un aperçu de la présence basque dans la baie des Chaleurs au XVIIe siècle." Revue d'histoire de l'Amérique française 68, 1/2: 125-51. Lugat, Caroline. 2006. "Les Traités de Bonne Correspondance: une derogation aux règles de droit maritime international? (XVIe-XVIIIe siècle).” Itsas Memoria. Revista de Estudios Maritimos del País Vasco 5: 301-08. Michelaki, Kostalina, Ronald G.V.Hancock, Gary Warrick, Dean Knight, Ruth H. Whitehead, and Ronald Farquar. 2015. "Using regional chemical comparisons of European copper to examine its trade to and among Indigenous groups in late 16th and early 17th century Canada: A case study from Nova Scotia and Ontario." Journal of Archaeological Science: Reports 4: 285-92.

Mimeault, Mario. 2011. Destins de pêcheurs. Les Basques en Nouvelle-France. Québec: Septentrion.

Nadon, Pierre. 2004. La Baie du Grand Pabos. Une seigneurie gaspésienne en Nouvelle-France au XVIII siècle. Québec: Association des archéologues du Québec.

Rankin, Lisa K., and Amanda Crompton. 2016. "Meeting in the Straits: Intersecting Inuit and European trajectories in southern Labrador.” In Brad Loewen and Claude Chapdelaine, eds., Contact in the 16th Century. Networks among Fishers, Farmers and Foragers in the Northeast, pp. 11-29. Ottawa: University of Ottawa Press.

Turgeon, Laurier. 1982. "Pêches basques en Atlantique nord (XVIIe-XVIIIe siècle): étude d'économie maritime." Ph.D. dissertation, Université de Bordeaux III.

-1997. "The tale of the kettle: Odyssey of an intercultural object." Ethnobistory 44, 1: 1-29.

- 1998. "French fishers, fur traders, and Amerindians during the sixteenth century: History and archaeology." William and Mary Quarterly, 3rd Series 55: 585-610.

Weyers, Christian. 2009. "Basque traces in the toponymy of Newfoundland and various coasts of Atlantic Canada." Proceedings of the 23rd International Congress of Onomastic Sciences (York University, Toronto): 1051-63. 